\title{
Investigating Foreign Direct Investment Attractive Factors of Korean Direct Investment into Vietnam*
}

\author{
Van Loi TA¹, Quoc Hoi LE², Thi Lien Huong NGUYEN³, Thuy Thao PHAN, Anh Duc DO \\ Received: March 24, 2020 Revised: April 11, 2020 Accepted: May 01, 2020
}

\begin{abstract}
This paper aims to investigate FDI attractive factors, which are important to formulate policies to attract Korean direct investment into Vietnam. Based on the literature review and the results of interview with 27 Korean investors in Vietnam, we determined the model of variables attracting Korea's FDI into Vietnam. It is used to assess the impact of attractive factors belonging to three groups of variables to support investment decision; they are macroeconomics variables (including market size factor, labor cost factor, and market openness factor), policies variables (including monetary policy factor and tax rate gap factor), and microeconomics variables (geographic advantage factor representative by location). This research also utilized a relatively new quantitative research method based on the Autoregressive Distributed Lag model (ARDL) with the time data chain from 1995 to 2017 of Korean FDI into Vietnam. It analyzes long-term relationships between dependent variables and independent variables. The result of this study indicates that there are three positive factors (low wages, trade openness and government policy) explaining the FDI flows in the long term. The result also shows that incentive tax policy has had a positive impact on Korean FDI, which has satisfied the aim of seeking efficiency of Korean investors.
\end{abstract}

Keywords : FDI, Attracting Factors, Korea, Vietnam.

JEL Classification Code: D22, F21, F23, G11, Q27

\section{Introduction}

Since the 1980s, money has flown across national borders in increasing volume from foreign direct investment

*This research is funded by National Economics University, Hanoi, Vietnam.

${ }^{1}$ First Author. Associate Professor, Dean, School of Trade and International Economics, National Economics University, Vietnam. Email: loitv@neu.edu.vn

${ }^{2}$ Associate Professor, Editor in Chief, Journal of Economics and Development, National Economics University, Vietnam. Email: hoilq@neu.edu.vn

${ }^{3} \mathrm{Head}$, International Trade Department, School of Trade and International Economics, National Economics University, Vietnam. Email: huongnltmai@neu.edu.vn

${ }^{4} \mathrm{Ph}$.D. Student, Lecturer, Economics Department, Faculty of Economics and Management, Thuy Loi University, Vietnam. Email: thaopt@tlu.edu.vn

${ }^{5}$ Corresponding Author. Lecturer, School of Trade and International Economics, National Economics University, Vietnam [Postal Address: 207 Giai Phong Road, Dong Tam Ward, Hai Ba Trung District, Hanoi, 113068, Vietnam] Email: ducda@neu.edu.vn

(c) Copyright: The Author(s)

This is an Open Access article distributed under the terms of the Creative Commons Attribution Non-Commercial License (http://Creativecommons.org/licenses/by-nc/4.0/) which permits unrestricted noncommercial use, distribution, and reproduction in any medium, provided the original work is properly cited.
(FDI) while global capital markets have become increasingly integrated. The flow of FDI is not only helpful to investors interested in diversifying their portfolios and increasing their returns by having access to faster growing markets, but also markets receiving capital flows gain access to desperately needed funds for their domestic savings which are mostly inadequate. Therefore, FDI is mostly studied from the perspective of the host country in terms of how foreign investors perceive an investment location and climate, how to become a 'destination' for investment in the future and how to keep the investors continue to make further investments in the country. A host country may be considered 'attractive' to foreign investors as it can stimulate foreign investors to form their intention and implement decision-making behaviors to choose investment capital. That is represented by the volume and value of FDI capital flows into the host country in a given period. Basically, the goals and desires of foreign investors are to reduce costs, reduce risks and increase revenue towards expected target profits.

Vietnam has become an attractive destination. It is known as a manufacturing hub and a growing domestic market with close proximity to consumers and global supply chain. Recently, with increasing awareness of government and consumers about environmental protection, Vietnam 
has been also paying attention to achieve sustainable development through policies related to green supplier, green supply chain activities, etc. South Korea is number one among all countries and territories investing in Vietnam up to present. Korean FDI in Vietnam has soared over time, starting at more than USD0.9 million capital with two registered projects in 1990. This capital inflow significantly increased to USD183 million in 1995 - 10 times greater than that of 1992. The upward trend continued until 1997, after the Bilateral Investment Treaty (BIT) established between Korea and Vietnam in 1993, which was considered as the effective driving force of FDI. However, due to the economic crisis in Korea in 1998, the number of Korean FDI in Vietnam during 1998-2001 period declined to the annual average capital of USD3 billion. This figure hit the second bottom in 2011, falling to USD1.285 billion, when Korea was affected by the second global financial crisis before rising sharply again. As of early 2020, total FDI capital flows from South Korea to Vietnam is approximate USD70 billion.

\section{Literature Review}

FDI flows record the value of cross-border transactions related to direct investment during a given period of time, usually a quarter or a year. Financial flows consist of equity transactions, reinvestment of earnings, and intercompany debt transactions. Outward flows represent transactions that increase the investment that investors in the reporting economy have in enterprises in a foreign economy. Inward flows represent transactions that increase the investment that foreign investors have in enterprises resident in the reporting economy less transactions that decrease the investment of foreign investors in resident enterprises. FDI creates stable and long-lasting links between economies. FDI flows are measured in USD and as a share of GDP.

Many of the world's leading companies have operations scattered around the globe. Declining incomes and consumption spending in the US and Europe have provided initial motivation behind their expansion to Asia, the MiddleEast and South America. Later, supply chain considerations became more important. Similarly, emerging market players like Tata Motors, Mittal Steel, Samsung or Cemex need consumers in US and Europe. While revenue growth of many US multinationals in the last decade came mainly from emerging markets, emerging market multinationals have also been gaining market shares in US and Europe.

The literature on the determinants of FDI is extensive. Two distinct approaches may be noted. Macro approaches draw on modern international trade theories to explain the location of multinational production. Micro or a firm-level approach explores the motivations behind FDI and try to explain why and which firms are more likely to become foreign investors. Both of these approaches explore variables that are either exogenous or endogenous to the firm that provide ownership advantages to be exploited abroad. They include such things as the management expertise, technological skills, firm size etc., (Dunning, 2001). Nevertheless, exogenous variables that affect a firm's FDI decisions, such as market size and labor costs and market imperfections, which imply some location advantages for establishing in a host country have been suggested among the FDI determinants (Markusen, 1984; Markusen \& Venables, 1998; Bergstrand, 1985; and Buckley \& Casson, 1976).

The literature has also addressed issues like the limitations of exporting and licensing as alternative forms of market entry. It is argued that trade restrictions and high transportation costs made exporting expensive and difficult. Also, internalization theory (also known as the market imperfections approach) pointed out major drawbacks of licensing as a strategy for exploiting foreign market opportunities such as giving away valuable technological know-how to a potential foreign competitor as well as not allowing the tight control over manufacturing, marketing, and strategy in a foreign country that may be required to maximize its profits (Dunning, 2003; Verbeke, 2003). The eclectic paradigm, championed by J. Dunning, argues that location-specific advantages (resource endowments or assets that are tied to a particular location) and externalities (knowledge spillovers that occur when companies in the same industry locate in the same area) are also of considerable importance in explaining both the rationale for and the direction of foreign direct investment (Dunning, 2003). Finally, using the analogy with the gravitational force in physics, the gravity model predicts that the volume of bilateral trade between two economies is determined by their relative sizes and distance.

In the trade literature, the volume of trade is positively associated with the size of economies, measured by GDP while it is negatively associated with the distance between them (Anderson, 1979; Frankel, 1997). More specifically, market size (and its growth) and relative factor prices are the most commonly used indicators of locational determinants of FDI. The implication is that countries with larger domestic markets tend to receive more FDI, because of higher demand potential and scale economies. The market growth hypothesis implies that fast growing economies exhibit more profit opportunities than those, which are growing more slowly or not at all (Lim, 1983). In addition, strategic asset acquisition is included among the motives for FDI along with resource seeking as well as lowering costs or improved efficiency (Buckley, 2018).

The experimental study result of Balasubramnanyam et al. (1996) indicated that opening the economy with incentive policy to boost exports will attract more FDI inward. To reflect the impact of this factor on attracting FDI into Vietnam, the author used the external exchange trade value variable as the 
Van Loi TA, Quoc Hoi LE, Thi Lien Huong NGUYEN, Thuy Thao PHAN, Anh Duc DO /

Journal of Asian Finance, Economics and Business Vol 7 No 6 (2020) 117 - 125

representative, similar to the study of Dauti Bardhyl (2015); Ren (2012); Anyanwu (2012); In addition, Vijayakumar et al. (2010) and Hoang (2012) used the Trade Openness variable measured by import and export as a share of GDP ([import + export]/GDP) which is expressed by the following factors: (1) Size and demand of the market (2) Level of science and technology (3) Human resources (4) Commercial scale. However, these four variables need more in-depth studies for the characteristics of FDI capital from Northeast Asian countries to Vietnam and the characteristics of variables belonging to Vietnam's investment environment.

The model of variables attracting Korea's FDI to Vietnam is used to assess the impact of attractive factors belonging to six factors of FDI investment decisions. They are determined through the result of interviews with 27 Korean investors in Vietnam as follows (see Table1):

\section{Research Methods and Materials}

\subsection{Research Model}

Based on the literature discussed above, the researchers determined the model as follows (see Figure 1). In this model (see Figure 1), variables are divided into three groups:

Group 1: Macroeconomics variables include Market size (represented by GDP), Labor cost (investor's point of view of labor cost between Vietnam and Korea, represented by Wage gap), Market openness (represented by the ratio of Trade on GDP).
Group 2: Policies mean the government's interference. In this research, policies variables only focus on two elements: monetary policy (including adjustment for inflation case and exchange rate case such as devalue money for supporting export, showing by inflation gap) and tax rate gap. Tax gap will occurred when Vietnam and/or Korea adjust tax rate by following cases:

[1]. Vietnam reduces tax rate

[2]. Korea increases tax rate

[3]. Vietnam reduce tax rate and/or Korea increase tax rate

[4]. Vietnam reduces tax rate more than Korea do

[5]. Vietnam increases tax rate less than Korea do (seldom)

Group 3: Microeconomics includes consideration on geographic advantage, which represented by location.

Table 1: Summary of factors attracting FDI from Korea

\begin{tabular}{|l|l|c|l|}
\hline No. & \multicolumn{1}{|c|}{ Factors } & Rating rate & Impact \\
\hline 1 & Potential market (GDP) & $85 \%$ & Positive \\
\hline 2 & Low Wage (WAGE GAP) & $95 \%$ & Positive \\
\hline 3 & $\begin{array}{l}\text { Market openness } \\
\text { (international Trade/GDP) }\end{array}$ & $80 \%$ & Positive \\
\hline 4 & $\begin{array}{l}\text { Monetary policy (Inflation } \\
\text { rate) }\end{array}$ & $80 \%$ & Positive \\
\hline 5 & $\begin{array}{l}\text { Attract FDI policy (FDI } \\
\text { Corporate tax) }\end{array}$ & $70 \%$ & Positive \\
\hline 6 & $\begin{array}{l}\text { Geographic advantage } \\
\text { (Location/distance) }\end{array}$ & $85 \%$ & Positive \\
\hline
\end{tabular}

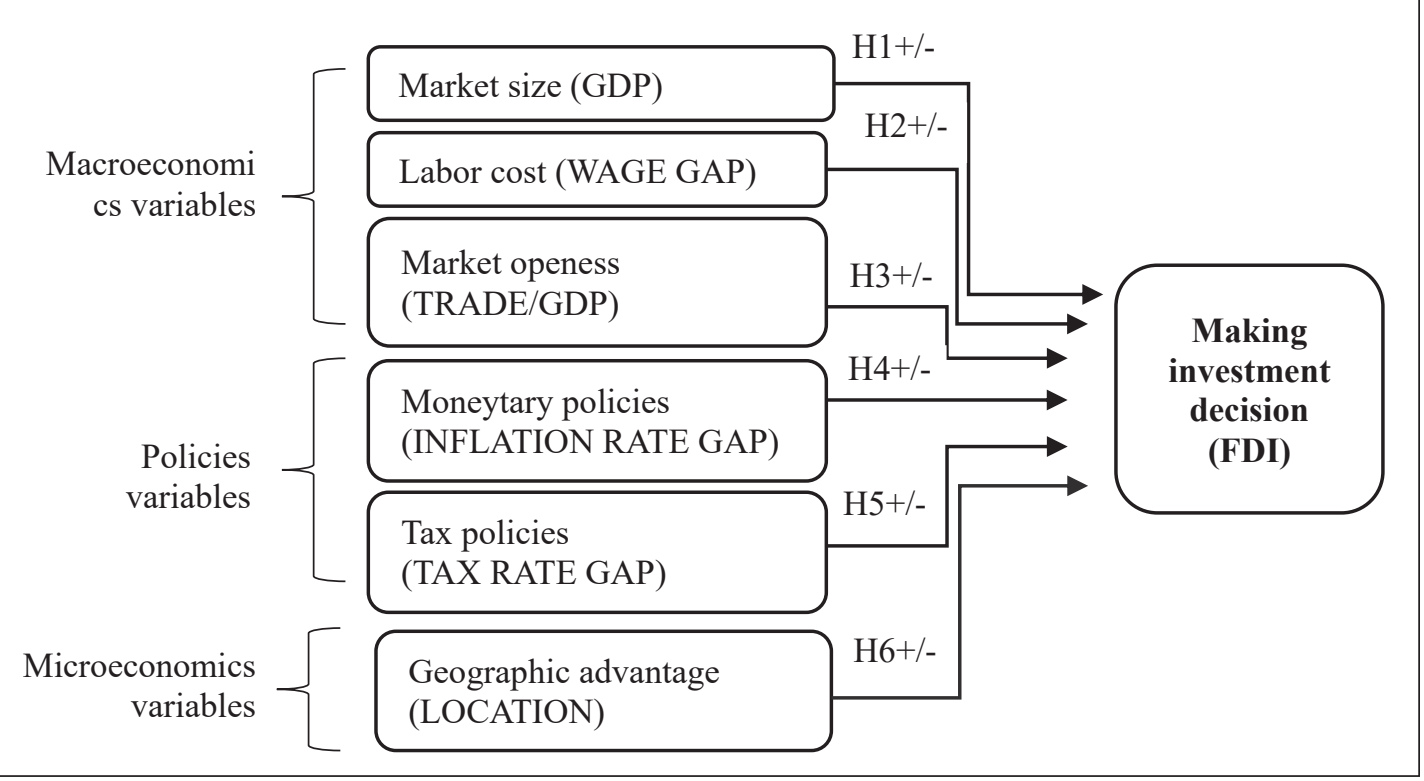

Figure 1: The impact of factors attracting FDI from Korea to Vietnam 


\subsection{Research Methods}

To examine whether there are long-term or short-term relationships between dependent variables and independent variables, the ARDL (Autoregressive-Distributed Lag) model is used in this study with time-series data. This model was developed by Pesaran and Smith (1998), nevertheless, Pesaran et al. (2001) popularized it (Rehman, Ilyas, Alam \& Akram, 2011). Some prior similar studies used the ARDL model for analyzing long-term relationships between dependent variables and independent variables (For example, Rehman et al., 2011; Ren, 2012, Alshamsi et al., 2015).

There are two main methods to be used in this study:

Unit root test: to examine the unit root of data series with each variable with two methods, which are Dickey-Fuller (ADF) and Phillips-Perron (PP).

ARDL Bounds Testing Approach to Cointegration: to examine the long-term and short-term relationship of dependent variables according to independent variables based on the procedures of Pesaran et al. (2001).

The formula of research as follow:

$$
\text { FDIijt=f(GDPjt, WAGEijt, TRADEjt, INFLAjt, TAXjt) }
$$

with year $=\mathrm{t}$; Korea is $\mathrm{i}$ and Vietnam is $\mathrm{j}$.

This study approach is time series Approach, Ren (2012), Pesaran \& Pesaran (1997), Pesaran \& Shin (1999) and Pesaran et al. (2001). However, the variables also have long term relationship so this research uses an Autoregressive Distributed Lag (ARDL).

Autoregressive Distributed Lag utilizes in as formula:

$$
\begin{aligned}
\operatorname{lnFDI} I_{t}= & \beta_{0}+\beta_{1} \ln G D P_{t}+\beta_{2} W A G E_{t}+\beta_{3} T R A D E_{t}+ \\
& \beta_{4} I N P L A_{t}+\beta_{5} T A X_{t}+\varepsilon_{t}
\end{aligned}
$$

When applying this formula for Korean FDI, this study focus on two contents:

Unit root test: For testing unit root we use model Augmented Dickey-Fuller (ADF) of Dickey-Fuller (1979) and Phillips-Perron (PP) with the indicator Akaike (AIC) and information of Schwartz (SIC) for the lag.

Bounds approach for lag with cointegration test:

$$
\begin{aligned}
& \Delta \operatorname{lnFDI} I_{t}=\alpha_{0}+\sum_{i=1}^{n} \alpha_{1 i} \cdot \Delta \ln F D I_{t-1}+\sum_{i=0}^{n} \alpha_{2 i} . \Delta \operatorname{LnGDP_{t-1}} \\
& +\sum_{i=0}^{n} \alpha_{3 i} \cdot \Delta W A G E_{t-1}+\sum_{i=0}^{n} \alpha_{4 i} \cdot \Delta T R A D E_{t-1} \\
& +\sum_{i=0}^{n} \alpha_{5 i} \cdot \Delta I N F L A_{t-1}+\sum_{i=0}^{n} \alpha_{6 i} \cdot \Delta T A X_{t-1} \\
& +\beta_{1} \ln G D P_{t}+\beta_{2} W A G E_{t}+\beta_{3} T R A D E_{t} \\
& +\beta_{4} I N P L A_{t}+\beta_{5} T A X_{t}+\varepsilon_{t}
\end{aligned}
$$

with $\Delta=$ deviation, $\varepsilon_{\mathrm{t}}$ is random with variable $\alpha_{\mathrm{ij}}$ and $\beta_{\mathrm{j}}$ is for short or long term.

For Wald test use for relationship cointegration test with the following hypothesis:

$\mathrm{H}_{0}: \beta_{1}=\cdots=\beta_{6}=0$ (no long term relationship between variables)

$\mathrm{H}_{1}: \beta_{1} \neq \cdots \neq \beta_{6} \neq 0$ (a long term relationship between variables)

\subsection{Data Sources}

Korea FDI data in Vietnam, the attractive factor variables of Vietnam's investment environment. The data is collected from 1995 to 2017 are reported in Table 2 as follows:

Moreover, the data used in this study is secondary data which is collected from trustworthy sources: the World Bank, the International Monetary Fund (IMF), the Organization for Economic Cooperation and Development (OECD), the General Statistics Office of Vietnam and the Foreign Investment Agency of the Ministry of Planning and Investment of Vietnam.

\section{Results and Discussion}

\subsection{Dickey-Fuller and Phillips-Perron Test}

The statistics are the result of the integrated level data chain. The results tested by Augmented Dickey-Fuller test (ADF) and the Phillips-Perron test (PP) are reported in Table 3. The results show that there are two sequences stop at the root step, or integrate tier 0 - I $(0)$, named as INFLAK and WAGEK. The remaining sequences stop at level 1 or integrate tier 1 - I(1).

The unit root test results show that the data series has a mixture of integration tier I(0) and I(1). Therefore, traditional OLS, VAR and VECM are not suitable methods in estimation. There are usually two ways to handle mixed integrated orders. There is one method to apply the OLS approach to other data series under a fixed level (Asteriou \& Hall, 2007). Another method is to apply ARDL method (Pesaran \& Pesaran, 1997). In order to explore the long-term effects, this study applies the second method of empirical estimation.

\subsection{ARDL Bounds Test for Cointegration}

Analysis of ARDL bounds test for cointegration is done through ARDL model. The AIC and SC criteria are used to select the optimal latency and the model is defined as ARDL $(1,2,2,2,2,2)$. The test results of the model are shown in Table 4. This model passes the tests of true function form, variance of random error variance, sequence self-correlation and standardized residual. Also, Table 4 shows that the F statistic is 75,5398 higher than the upper critical value of $5 \%$ significance. This indicates that a coherent relationship was found between the variables, considering the case of Vietnam from 1995 to 2017. 
Van Loi TA, Quoc Hoi LE, Thi Lien Huong NGUYEN, Thuy Thao PHAN, Anh Duc DO /

Journal of Asian Finance, Economics and Business Vol 7 No 6 (2020) 117 - 125

Table 2: The attractive factor variables of Vietnam's investment environment from 1995 to 2017

\begin{tabular}{|c|c|c|c|c|c|c|c|c|}
\hline Year & Country & LFDIK & LGDP & TRADE & INFLA & WAGE & TAX & LOCAL Dummy \\
\hline 1995 & Korea & 6.38 & 9.94 & 74.72 & 17.04 & 34.64 & 35 & 1 \\
\hline 1996 & Korea & 6.73 & 10.11 & 92.71 & 8.70 & 33.76 & 35 & 1 \\
\hline 1997 & Korea & 6.79 & 10.20 & 94.34 & 6.60 & 30.73 & 35 & 1 \\
\hline 1998 & Korea & 4.61 & 10.21 & 97.00 & 8.84 & 29.21 & 35 & 1 \\
\hline 1999 & Korea & 5.22 & 10.26 & 102.79 & 5.73 & 28.21 & 35 & 1 \\
\hline 2000 & Korea & 4.59 & 10.35 & 111.42 & 3.41 & 25.28 & 35 & 1 \\
\hline 2001 & Korea & 5.27 & 10.39 & 111.96 & 2.62 & 24.37 & 35 & 1 \\
\hline 2002 & Korea & 6.32 & 10.46 & 116.70 & 4.70 & 24.11 & 35 & 1 \\
\hline 2003 & Korea & 6.17 & 10.59 & 124.33 & 7.11 & 23.59 & 35 & 1 \\
\hline 2004 & Korea & 6.20 & 10.72 & 133.02 & 8.43 & 22.66 & 35 & 1 \\
\hline 2005 & Korea & 6.83 & 10.96 & 130.71 & 18.81 & 23.59 & 35 & 1 \\
\hline 2006 & Korea & 8.04 & 11.10 & 138.31 & 8.57 & 22.50 & 35 & 1 \\
\hline 2007 & Korea & 8.59 & 11.26 & 154.61 & 9.63 & 21.65 & 35 & 1 \\
\hline 2008 & Korea & 8.50 & 11.50 & 154.32 & 22.67 & 20.58 & 35 & 1 \\
\hline 2009 & Korea & 7.56 & 11.57 & 134.71 & 6.22 & 19.98 & 25 & 1 \\
\hline 2010 & Korea & 7.84 & 11.66 & 152.22 & 12.07 & 19.31 & 25 & 1 \\
\hline 2011 & Korea & 7.34 & 11.82 & 162.91 & 21.26 & 18.86 & 25 & 1 \\
\hline 2012 & Korea & 7.16 & 11.96 & 156.55 & 10.93 & 18.02 & 25 & 1 \\
\hline 2013 & Korea & 8.40 & 12.05 & 165.09 & 4.76 & 17.73 & 25 & 1 \\
\hline 2014 & Korea & 8.95 & 12.13 & 169.53 & 3.66 & 17.02 & 22 & 1 \\
\hline 2015 & Korea & 8.85 & 12.17 & 178.77 & 0.63 & 16.42 & 22 & 1 \\
\hline 2016 & Korea & 8.98 & 12.23 & 184.69 & 1.11 & 15.93 & 20 & 1 \\
\hline 2017 & Korea & 9.07 & 12.32 & 200.38 & 4.09 & 15.65 & 20 & 1 \\
\hline
\end{tabular}

Table 3: Results unit root tests

\begin{tabular}{|l|c|c|c|c|c|}
\hline \multirow{2}{*}{ Variables } & \multicolumn{2}{|c|}{ ADF test } & \multicolumn{2}{|c|}{ PP test } & \multirow{2}{*}{ Conclusion } \\
\cline { 2 - 5 } & Original & First order difference & Original & First order difference & \\
\hline IFDIK & -0.926102 & $-4.531783^{\star * *}$ & -0.926102 & $-4.531783^{\star * *}$ & $\mathrm{I}(1)$ \\
\hline LGDPK & -0.179418 & $-3.018671^{* *}$ & -0.226543 & $-3.018671^{* * *}$ & $\mathrm{I}(1)$ \\
\hline INFLAK & $-3.314003^{* *}$ & & $-3.321376^{* *}$ & & $\mathrm{I}(0)$ \\
\hline TAXK & -0.101805 & $-4.842125^{\star * *}$ & -0.016785 & $-4.843706^{\star * *}$ & $\mathrm{I}(1)$ \\
\hline TRADEK & 0.249875 & $-6.278423^{* * *}$ & -0.112697 & $-8.143207^{* * *}$ & $\mathrm{I}(1)$ \\
\hline WAGEK & $-3.151805^{* *}$ & & $-3.551386^{* *}$ & & $\mathrm{I}(0)$ \\
\hline
\end{tabular}

Note: ${ }^{* * *},{ }^{* *}$ correspond to stopping at a significant level of $1 \%, 5 \%$ and $10 \%$

The stability of ARDL estimation results is reviewed through CUSUM and CUSUMSQ tests (see Figure 2).

In both cases, the graph did not cross the critical line at the $5 \%$ significance level, which is a testament to the stability of the parameters obtained in the ARDL model. This confirms a stable and meaningful relationship between the variables included in the model. Cointegration equations and estimated long-term coefficients are given in Table 5:

Table 5 shows that in the long term, the factors TAX_K, TRADE_K, WAGE_K have all positive impact on Korean 
Table 4: ARDL model results $(1,2,2,2,2,2)$ and cointegration test

\begin{tabular}{|c|c|c|}
\hline \multicolumn{3}{|c|}{ Estimated results and diagnostic test of ARDL $(1,2,2,2,2,2)$} \\
\hline R-squared $=0.9967$ & \multicolumn{2}{|c|}{ R-squared correction $=0.9835$} \\
\hline F-statistic $=75.5398$ & \multicolumn{2}{|l|}{ Pro. $=0.0003$} \\
\hline Serial correlation & \multicolumn{2}{|c|}{ LM $=11.8084$, Prob. $=0.0027$} \\
\hline Calibration & \multicolumn{2}{|c|}{$\mathrm{JB}=12.327$, Prob. $=0.0021$} \\
\hline Correct function form & \multicolumn{2}{|c|}{$F=0.0599$, Prob. $=0.9434$} \\
\hline Constant variance (BPG) & \multicolumn{2}{|c|}{ LM $=8.7943$, Prob. $=0.4314$} \\
\hline \multicolumn{3}{|c|}{ Bounds test for cointegration } \\
\hline \multicolumn{3}{|l|}{ Statistical value $\mathrm{F}=8.9719$} \\
\hline \multirow{2}{*}{ Level of significance } & \multicolumn{2}{|c|}{ Limited value } \\
\hline & Upper boundary (10) & Lower boundary (I1) \\
\hline $10 \%$ & 2.08 & 3 \\
\hline $5 \%$ & 2.39 & 3.38 \\
\hline $2.5 \%$ & 2.7 & 3.73 \\
\hline $1 \%$ & 3.06 & 4.15 \\
\hline
\end{tabular}

Table 5: Cointegrating results and long-term coefficients

\begin{tabular}{|c|c|c|c|c|}
\hline \multicolumn{5}{|l|}{ Cointegration form } \\
\hline Independent variables & Coefficient & Standard error & Statistics $\mathbf{t}$ & Probability \\
\hline D(INFLA_K1) & 0.130703 & 0.013954 & 9.366418 & 0.0007 \\
\hline D(INFLA_K1(-1)) & -0.117967 & 0.006270 & -18.814082 & 0.0000 \\
\hline $\mathrm{D}(\mathrm{LGDP}$ _K1) & -28.423068 & 2.017234 & -14.090118 & 0.0001 \\
\hline $\mathrm{D}($ LGDP_K1(-1)) & 5.129543 & 0.898889 & 5.706538 & 0.0047 \\
\hline $\mathrm{D}\left(\mathrm{TAX} \_\mathrm{K} 1\right)$ & 0.169410 & 0.017701 & 9.570731 & 0.0007 \\
\hline $\mathrm{D}\left(\mathrm{TAX} \_\mathrm{K} 1(-1)\right)$ & -0.140739 & 0.021246 & -6.624406 & 0.0027 \\
\hline $\mathrm{D}\left(\mathrm{TRADE} \_\mathrm{K} 1\right)$ & 0.013391 & 0.004751 & 2.818762 & 0.0479 \\
\hline D(TRADE_K1(-1)) & 0.060308 & 0.006239 & 9.666658 & 0.0006 \\
\hline D(WAGE_K1) & 0.696229 & 0.043097 & 16.154919 & 0.0001 \\
\hline D(WAGE_K1(-1)) & 1.164123 & 0.061455 & 18.942558 & 0.0000 \\
\hline CointEq(-1) & -1.429393 & 0.074709 & -19.132750 & 0.0000 \\
\hline \multicolumn{5}{|c|}{ 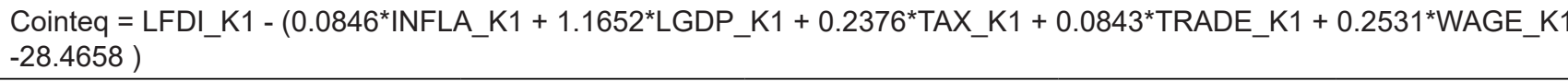 } \\
\hline \multicolumn{5}{|c|}{ Estimate long-term coefficients } \\
\hline Independent variables & Coefficient & Standard error & Statistics $\mathbf{t}$ & Probability \\
\hline INFLA_K1 & 0.084641 & 0.035005 & 2.417933 & 0.0729 \\
\hline LGDP_K1 & 1.165174 & 0.760742 & 1.531628 & 0.2004 \\
\hline TAX_K1 & 0.237620 & 0.030471 & 7.798270 & 0.0015 \\
\hline TRADE_K1 & 0.084306 & 0.017316 & 4.868574 & 0.0082 \\
\hline WAGE_K1 & 0.253098 & 0.037080 & 6.825809 & 0.0024 \\
\hline C & -28.465841 & 7.363745 & -3.865674 & 0.0181 \\
\hline
\end{tabular}



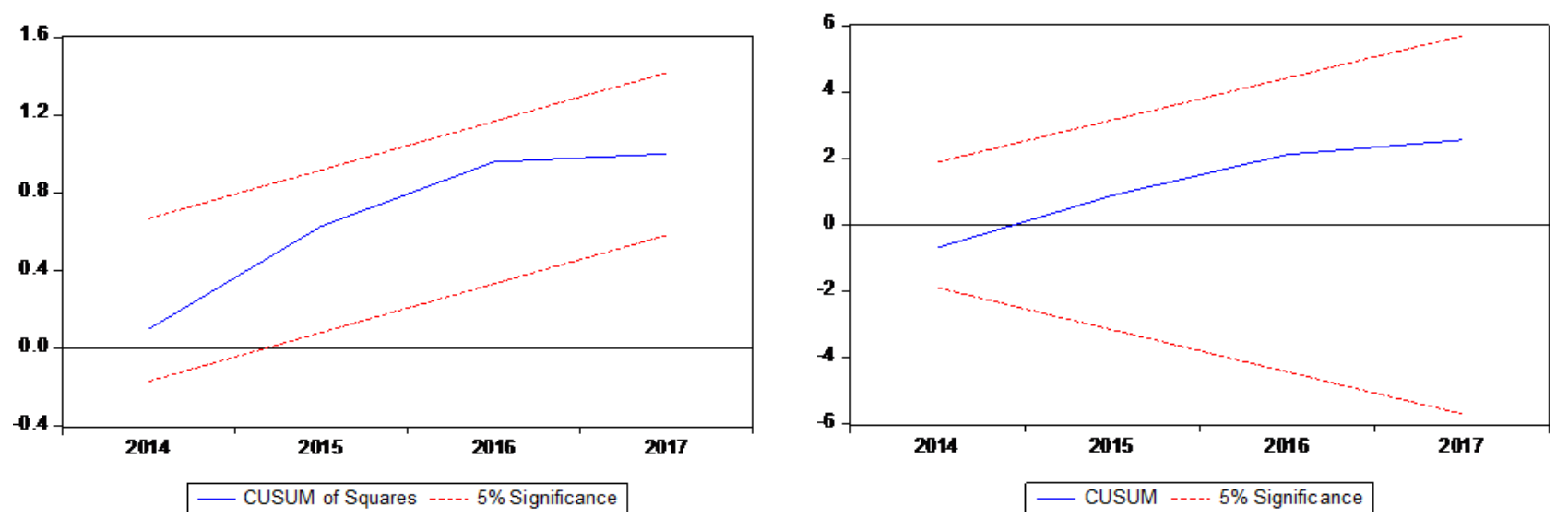

Figure 2: Graph of CUSUM and CUSUMSQ test results

FDI into Vietnam at a significant level of 5\%. In particular, the influence of WAGE_K is greatest, when WAGE_K is increased by $1 \%$, the Korean FDI in Vietnam increased to $0.25 \%$; followed WAGE_K is the influence of TAX_K in the second, when WAGE_K is increased by $1 \%$, the Korean FDI in Vietnam is increased to nearly $0.25 \%$; and when the effect of TRADE_K is increased by $1 \%$, Korean FDI in Vietnam is increased by about $0084 \%$, very little.

In addition, as expected, the error correction factor, i.e. ECTt-1, is negative and statistically significant at $1 \%$. This confirms the long-term relationship between the variables that have been established earlier. ECTt-1 coefficient of -1.4293 implies that FDI adjusts very quickly to the longterm equilibrium at a rate of $142.93 \%$ after each year. In the short term, the coefficients of the independent variables are highly significant at $5 \%$ except instead of minus the variable TRADE_K of year $t$ without affecting the amount of FDI in year $t$. In particular, the variable WAGE_K of year $t$ and $(t-1)$ has a positive coefficient $(+)$, positive in the same direction with the meaning that the difference in wages in years $t-1$ and $t$ increases by $1 \%$, the FDI of year $t$ increases to $1.16 \%$ and $0.69 \%$ respectively. The variable TRADE_K (-1) has a positive impact on FDI in year $t$, receiving a value of 0.06 . The pair of variables TAX_K, TAX_K (-1) and INFLA_K, INFLA_K (-1) take the value of (+) in year $t$ and (-) in year $(\mathrm{t}-1)$. Finally, the variable LGDP_K, LGDP_K (-1) times the value $(-)$ in year $t$ and $(+)$ in year $(\mathrm{t}-1)$.

\section{Conclusions}

This study has applied an econometric research methodology after collecting data from secondary sources as well as result of surveys of 27 Korean investors into Vietnam. The study has also utilized a relatively new quantitative research method based on ARDL to investigate the impact of market size factor (represented by GDP), labor cost (investor's point of view of labor cost between Vietnam and Korea, represented by Wage gap), market openness (represented by the ratio of Trade on GDP), monetary policy factor (including adjust for inflation case and exchange rate case such as devalue money for supporting export, showing by inflation gap), tax rate gap factor, and geographic advantage factor (represented by location) on Korean FDI into Vietnam from 1995 to 2017. There have been some significant findings from this study.

Firstly, the factors of wage differential and trade openness have positive impacts on Korean FDI in both short and long term. This result is consistent with the findings of previous studies (Ren, 2013; Carstensen \& Toubal, 2004) and is in line with expectations garnered from respondents to a survey of 27 Korean investors in Vietnam. Within their objects is investigating efficiencies, which is appropriate with capital structure when $60 \%$ Korean FDI projects in Vietnam are in the manufacturing sector, especially garment, leather shoes, high-tech electronics. Korean investors have been searching for low-cost manufacturing sites, and then most of products will be exported to markets outside of Vietnam. It also explains the reason why the market size only has a shortterm impact, in which, the market size of the year $(\mathrm{t}-1)$ has a positive effect on FDI and year ( $t$ ) has a negative effect and quickly changes into no impact on long term. This variable has had no effect, as the Vietnamese market has not been the potential market for Korea because of the fact that Korean products are often more expensive compared to Vietnamese people incomes, hence there are not many households that can afford for these products.

The second finding relates to incentive policies, especially incentive tax policy; this finding is also in line with previous research about Vietnamese attractive factors. Incentive tax policy has had a positive impact on Korean FDI, which has satisfied the aim of seeking efficiency of Korean investors. According to Kang \& Lee (2007), Korean FDI flow, with the 
aim of seeking for efficiency, tends to move Chinese FDI flow to third countries such as India and South-East Asia to invest after China restricts incentive policies as well as increases average income.

Last, but not least, to investigate FDI attractive factors of Korean Direct Investment into Vietnam in the aspect of investors, future work can use primary data from Korean investors in Vietnam, which will bring a more persuasive result. This study will help to formulate policies to attract Korean direct investment into Vietnam in the next period.

\section{References}

Alshamsi, K. H., Hussin, M. B., \& Azam, M. (2015). The impact of inflation and GDP per capita on foreign direct investment: the case of United Arab Emirates. Investment Management and Financial Innovations, 12(3), 53-74.

Anderson, J. E. (1979). A theoretical foundation for the gravity equation. The American economic review, 69(1), 106-116.

Anyanwu, J. C. (2012). Why Does Foreign Direct Investment Go Where It Goes?: New Evidence From African Countries. Annals of Economics \& Finance, 13(2), 425-462.

Asteriou, D. \& Hall, S.G. (2007). Applied Econometrics: A Modern Approach Using E-views and Microfit. New York: Palgrave Macmillan.

Balasubramanyam, V. N., Salisu, M., \& Sapsford, D. (1996). Foreign direct investment and growth in EP and IS countries. The economic journal, 106(434), 92-105.

Bergstrand, J.H. (1985). The Gravity Equation in International Trade: Some Microeconomic Foundations and Empirical Evidence. Review of Economics and Statistics, 67(3), 474-481.

Buckley, P.J. (2018). Internalisation theory and outward direct investment by emerging market multinationals. Management International Review, 58(2), 195-224.

Buckley, P.J. \& Casson, M. (1976). The Future of the Multinational Enterprise. London: Macmillan.

Carr, D.L., Markusen, J.R. \& Maskus, K.E. (2001). Estimating the knowledge-capital model of the multinational enterprise. American Economic Review, 91(3), 693-708.

Carstensen, K., \& Toubal, F. (2004). Foreign direct investment in Central and Eastern European countries: a dynamic panel analysis. Journal of comparative economics, 32(1), 3-22.

Dauti Bardhyl (2015). Determinants of foreign direct investment in South East European countries and new member states of European Union countries. Economic \& Business Review, 17(1), 93-115.

Dickey, D. A., \& Fuller, W. A. (1979). Distribution of the estimators for autoregressive time series with a unit root. Journal of the American statistical association, 74(366), 427-431.

Do, A.D., \& Luu, H.V. (2019). Developing a quality function deployment method for selecting and evaluating suppliers. Journal of Economics and Development, 262(4), 80-88.
Do, A.D., Nguyen, Q.V., Nguyen, D.U., Le, Q.H., \& Trinh, D.U. (2020), Green supply chain management practices and destination image: Evidence from Vietnam tourism industry. Uncertain Supply Chain Management, 8(2020) 371-378. DOI: 10.5267/j.uscm.2019.11.003

Dunning, J. (2003). Some Antecedents of Internalization Theory. Journal of International Business Studies, 34(2), 108-115.

Dunning, J. H., (2001). The eclectic (OLI) paradigm of international production: Past, present and future. International Journal of the Economics of Business, 8(2), 173-190.

Erum N., Hussain S., \& Yousaf A. (2016). Foreign Direct Investment and Economic Growth in SAARC Countries. Journal of Asian Finance, Economics and Business, 3(4), 57-66. https://doi. org/10.13106/jafeb.2016.vol3.no4.57

Frankel, J.A. (1997). Regional trading blocs in the world economic system. Peterson Institute for International Economics

Ho, D.B., Pham V.M., Pham V.T., \& Truong N.H. (2018). A Stochastic Analysis of Vietnam Bilateral Trade Efficiency. Journal of Economics and Development, 20(2), 28-37.

Hoang, H. H. (2012). Foreign direct investment in Southeast Asia: Determinants and spatial distribution. No. 30, Working Papers, Development and Policies Research Center (DEPOCEN), Vietnam

Kang, S. J., \& Lee, H. S. (2007). The determinants of location choice of South Korean FDI in China. Japan and the world economy, 19(4), 441-460.

Lim, D. (1983). Another look at growth and defense in less developed countries. Economic Development and Cultural Change, 31(2), 377-384.

Markusen, J.R. (1984). Multinationals, multi-plant economies and the gains from trade. Journal of International Economics, 16(34), 205-226.

Markusen, J.R., \& Venables, A.J. (1998). Multinational Firms and the New Trade Theory. Journal of International Economics, 46(2), 183-203.

Nguyen, H.H. (2020). Impact of Foreign Direct Investment and International Trade on Economic Growth: Empirical Study in Vietnam. Journal of Asian Finance, Economics and Business, 7(3), 323-331. https://doi.org/10.13106/jafeb.2020.vol7. no3.323

Pesaran, H. M. \& Pesaran, B. (1997). Microfit 4.0. Oxford University Press.

Pesaran, M. H., \& Smith, R. P. (1998). Structural analysis of cointegrating VARs. Journal of Economic Surveys, 12(5), 471505.

Pesaran, M. H., Shin, Y. \& Smith, R. J. (2001). Bounds testing approaches to the analysis of level relationships. Journal of applied econometrics, 16(3), 289-326.

Pesaran, M., \& Shin, Y. (1999). An Autoregressive Distributed-Lag Modelling Approach to Cointegration Analysis. In S. Strøm (Ed.), Econometrics and Economic Theory in the 20th Century: The Ragnar Frisch Centennial Symposium (Econometric 
Van Loi TA, Quoc Hoi LE, Thi Lien Huong NGUYEN, Thuy Thao PHAN, Anh Duc DO /

Journal of Asian Finance, Economics and Business Vol 7 No 6 (2020) 117 - 125

Society Monographs, pp. 371-413). Cambridge: Cambridge University Press. DOI:10.1017/CCOL521633230.011

Qamruzzaman, M., Karim S., \& Wei J. (2019). Does Asymmetric Relation Exist between Exchange Rate and Foreign Direct Investment in Bangladesh? Evidence from Nonlinear ARDL Analysis. Journal of Asian Finance, Economics and Business, 6(4), 115-128. https://doi.org/10.13106/jafeb.2019.vol6. no4.115

Rehman, C. A., Ilyas, M., Alam, H. M., \& Akram, M. (2011). The impact of infrastructure on foreign direct investment: The case of Pakistan. International Journal of Business and Management, 6(5), 268-276. DOI:10.5539/ijbm.v6n5p268
Ren, J. (2012). Determinants and impact of foreign direct investment in China: a national and regional analysis. Leicestershire, UK: Doctorial dissertation, Loughborough University.

Thu, L.A., Fang, S., \& Kessani, SS. (2019). Factors influencing Vietnam's handicraft export with the gravity model. Journal of Economics and Development, 21(2), 32-41.

Verbeke, A. (2003). The Evolutionary View of the MNE and the Future of Internalization Theory. Journal of International Business Studies, 34(6), 498-504.

Vijayakumar, N., Sridharan, P., \& Rao, K. C. S. (2010). Determinants of FDI in BRICS Countries: A panel analysis. International Journal of Business Science \& Applied Management, 5(3), $1-13$. 